\title{
WTO 加盟下の中国のフードシステム
}

\author{
木 南 莉 莉*，木 南 章**
}

\section{1. 序}

中国の WTO 加盟に対しては，巨大な市場の開放に対する期待と国内経済・国際経済への影響 に対する懸念から，内外から多くの関心を集めている。しかしながら OECD [8] を始めとして， 中国の WTO 加盟の影響に関する近年の研究は, 産業の部門単位での分析が多いという特徵があ る。さらにそそこでの議論は最終的には生産コストの問題に重点が置かれているように思われる。 また,とりわけ農業部門への影響に対する関心は高く, Anderson, Huang and Ianchovichina [1], Colby, Diao and Tuan [2], Huang and Rozelle [4]，盧 [8] など，すでに多数の研究成果があ げられている。中国の国民経済において，農業は食料・原材料の供給源のみではなく，雇用，所 得創出の場としても重要な役割を果たしている。さらに，中国経済が抱える最大の問題が農村の 貧困問題と地域間格差問題であることを考元れば，農業部門に注目が集まるのは当然であろう。 しかしながら，近年の中国農業には大きな変化が生じていることも事実である。例えば，GDP に 占める農業部門の割合の急速な低下である（1980 年の $30 \%$ から 2000 年には $16 \%$ となってい る)。また,一次産品および食料が貿易に占める割合も, 輸出では, 1980 年にはそれぞれ $50 \%, 17 \%$

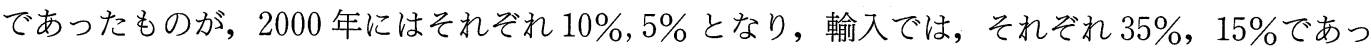
たものが，2000 年にはそれぞれ $21 \%, 2 \%$ となっている (表 1 を参照)。さらに，農村住民の所得 に占める非農業所得の割合が増加し，農業所得の割合が低下してきている(表 2 を参照)。その一 方で，すでに農業と他産業との結びつきが強まっており，国民の食生活を支えると同時に加工食 品の輸出が増加している（1997 年時点の食品輸出額は約 126 億ドルに達し, 総輸出額の $6.9 \%$ を 占めている)。このような変化を踏まえて, Anderson, Huang and Ianchovichina [1] は, WTO 加盟による影響について, 農工間や地域間（東部・西部間）の格差は拡大するものの，農村にお ける非農業部門の拡大と賃金の上昇によって都市・農村間の格差は縮小するとしている。

中国の WTO 加盟は，国際競争力の弱い中国農業に大きな影響を与えることが予想されている が，同時に，農業から食品製造業，流通業を経て消費者に至るフードシステム全体饮様々な影響 を与えるものと考元られる。さらに，相互依存関係を深めているアジア諸国の農業や食品産業に も影響を及湾すと考えられる。したがって，中国の WTO 加盟が中国農業に与える影響だけでは なく，農業を含むフードシステム，すなわち，農業・食品産業・食品流通業を全体に目を向けて その影響を検討する必要がある。そこで本研究では，中国のフードシステムの現状を分析したう

* 新潟大学

** 東京大学 
表 1 中国経済における農業の位置 単位：\%

\begin{tabular}{|l|c|c|c|}
\hline & 1980 & 1990 & 2000 \\
\hline GDP 構成割合 & & & \\
農業 & 30 & 27 & 16 \\
工業 & 49 & 42 & 51 \\
サービス業 & 21 & 31 & 33 \\
\hline 就業者構成割合 & & & \\
農業 & 69 & 60 & 50 \\
工業 & 18 & 21 & 23 \\
サービス業 & 13 & 19 & 27 \\
\hline 輸出構成割合 & & & \\
一次産品 & 50 & 26 & 10 \\
食料 & 17 & 11 & 5 \\
\hline 輸入構成割合 & & & \\
一次産品 & 35 & 19 & 21 \\
食料 & 15 & 6 & 2 \\
\hline 農村人口割合 & 81 & 72 & 64 \\
\hline
\end{tabular}

資料：「中国統計年鑑」各年版による。
表 2 農村家庭の収入源

\begin{tabular}{|l|r|r|r|r|}
\hline \multicolumn{1}{|c|}{} & \multicolumn{1}{c|}{ 単位: 元, \% } \\
\hline 純所得 & 1985 & 1990 & 1995 & \multicolumn{1}{c|}{2000} \\
家庭経営収入 & 397.60 & 686.31 & $1,577.74$ & $2,210.34$ \\
農業収入 & 191.46 & 518.55 & $1,125.79$ & $1,448.36$ \\
労働者収入 & 71.71 & 138.80 & 353.70 & 630.26 \\
所得移転 & 29.91 & 28.93 & 98.25 & 131.72 \\
\hline 構成比 & & & & \\
家庭経営収入 & 74.3 & 75.6 & 71.4 & 65.5 \\
農業収入 & 48.2 & 48.1 & 49.1 & 39.9 \\
労働者収入 & 18.0 & 20.2 & 22.4 & 28.5 \\
所得移転 & 7.5 & 4.2 & 6.2 & 6.0 \\
\hline
\end{tabular}

資料：「中国統計年鑑」各年版より作成。

えで, 国際産業連関表を用いたフードシステムの部門間の相互依存関係, 国外の農業・食品産業 との相互依存関係を明らかにし，WTO 加盟がそれらに与える影響を明らかにする。

\section{2. フードシステムと「農業産業化」}

\section{1 フードシステムとは何か}

フードシステムは「食」「農」十「食品産業」というフレームで理解しようとする試みである。 「農」十「食品産業」 $\rightarrow$ 「食」というフレームを川の流れに例えるならば，すなわち，われわれが食 する食料・食品は，まず「川上」の農水産業で生産され，それが「川中」の食品製造業，食品卸 売業, 「川下」の食品小売業, 外食産業を経て,「みずうみ」にたとえられる最終消費である食生 活に到達するのである。

このような枠組みで食料問題・農業問題を捉えようとする理由は，近年の「食」をめぐる大き な構造変化が生じたことにある。すなわち,「食の外部化」が進み, 総菜や調理済み冷凍食品など の急成長によって「中食」という新産業が誕生し, さらにそれらの結果, かつて近距離にあった 「食」と「農」との距離が拡大したことである（高橋 [12]）。このような現象は先進国のみではな く，中国を含む一部の途上国においても起こりつつある。

一方, 経済のグローバリゼーションは消費者の嗜好から末端の農村経済にまで浸透し, さらに 国境を越えた産業間の結び付きを強めている（木南・木南 [5])。したがって，農業問題・食料問 題を従来の理論モデルで理解するのが困難になってきている。そのため,近年日本においてはフー ドシステム学という新たな学問分野が構築されつつある。わが国における研究は, フードシステ 厶学会を中心に, 高橋 $[11]$, 斎藤 $[10]$, 時子山 [13] を始めとする研究の蓄積がある。欧米に 
おいてもフードチェーンという視点からのアプローチが頻繁に用いられている。

\section{2 「農業産業化」(Agricultural Industrialization)}

中国では, フードシステムという用語は用いられないものの, 農業政策の課題の一つに「農業 産業化」がある。これは, 農家の組織化を通じて生産・加工・流通の各過程における管理方法や 技術・品質の向上を図り, 中国農業の国際競争力を強化することである。すなわち，農民が農産 物の生産過程からだけではなく, 加工・流通過程からも収入を得て所得を拡大することを目指し ている。ただし，「農業産業化」について中国国内では二つの異なる見解がある。一つは欧米諸国 に追随して, 企業的なインテグレーションを図るべきであるというものである。もうひとつは, 中 国はまだ発展途上にあるため, 発展段階に適した独自の道を模索すべきであるというものである。 中国における農業産業化は，市場とは疎遠な農家のために市場を開拓し，そこから利益を上げる ノウハウと経験を持つ各種組織がパートナーとなって推進される。この方式は, 1980 年代の中頃 から中国東部の経済が発展した地域で始まり, 近年急速に普及している。農産物の種類別では, 食 糧・綿花・搾油作物等の主要作物よりも牧畜・水産・野菜・果物などにおける普及速度が速い。 農家のパートナーとなっている組織数は, 1996 年の 11,800 から, 1998 年には 30,300, 2000 年末 では 66,800 に増加した。同組織の代表的なタイプは次の 3 つである。

（1）龍頭企業 (中核企業)：農産物の加工，流通に携わる企業が主体で，27,000 力所 (約 40\%) ある。

（2）仲介組織：流通，加工等の分野でサービスを提供するもので，22,000 カ所（約 33\%）

（3）専門市場：特定の農産物を専門に扱う市場で， 7,600 力所(約 $11 \%$ )。これに関係する農家 は, 中国の総農家数の $1 / 4$ に当たる 5,900 万戸に達している。

また，各種組織と農家が結びつく形態には主に次の 5 つがある。

（1）契約：農家と生産・販売契約を結び，品種・面積・数量・買取価格等を決定する。

（2）提携：企業が出資し, 農民が労働力を提供して生産基地を造り, 企業が基地の農産物を買 い上げる。

（3）会員制：各種の協会を設立し，農家が会員となり，協会が必要なサービスを提供する。

（4）株式制：農民が龍頭企業の株主となって経営に参加し，配当を受け取る。

（5）土地の賃貸請負制：企業が農民から土地を賃借し，農民が生産を請け負う。

\section{WTO 加盟が中国のフードシステムに与える影響}

\section{1 農業および農産物貿易への影響}

WTO 加盟は, 中国農業を国際経済という大きな舞台に立たせ, 自身の比較優位と比較劣位につ いての再認識を余儀なくされることになる。比較劣位は, 農業労働力と比して耕地面積が少ない ところにある。中国の一農家当りの平均経営面積は 0.55 ha であり, 日本や韓国のそれの半分にも 及ばず，アメリカの $1 / 332$, オーストラリアの $1 / 7,702$ しかない。このことは土地集約型農産物の 
生産が中国にとっては不利であることを意味している。例えば，小麦・トウモロコシ・大豆・菜 種・糖類などの生産コストは高く，それらの国内価格は国際市場価格よりも約 10～50\% 高いので ある。国務院発展研究センターによれば, 農産物市場の開放が中国国内の農業に与える衝撃は, 主 に外国からの良質で低価格の農産物の輸入によるものである。とくに，穀物などの農産物輸入は， 国内農産物の価格を低下させ，国内農産物市場のシェアを奪い，農民の収入が減少することにつ ながる。国務院経済発展中心 [3] の計量モデルの分析結果によれば，2005 年までに，農業総生産 が $2 \% ，$ 農民の収入が 280 億元ほどそれぞれ減少すると見込まれている。

しかし，一方では中国農業の比較優位は，まず人件費が安くかつ豊富な農村労働力を有してい ることにある。このことは労働集約型農産物の生産が中国にとって有利となるはずである。例え ば，野菜・果物・園芸・水産・畜産などの部門における生産物価格は国際市場に比べて約 40～50\% 低いのである。また，中国は多様な自然条件を有するという比較優位も持っており，地域の特徵 を活かした「特産品」の発展に有利な条件を備えているのである。現在，中国全土では約 2,000 の 県・市が「中国特産品の町」に指定されている。

ところで，中国において農業は最も早い時点で外国資本に開放された産業ではあったが，残念 ながら他の産業に比べると外資導入の実績は最も良くなかった。外国資本が中国の農業への投資 に躊躇した原因としては以下の二つが考えられる。一つは中国の農地制度である。家族経営を基 本とする小規模の伝統的な農法は，先進的な技術を持ちかつ大規模な生産を要求する外国資本の 導入には適さなかった。もう一つは政府の介入である。中国政府が，穀物およびその他の主要農 産物の生産から価格の制定・買い上げ・貯蔵・輸送・国内販売・国外への輸出までの，全ての過 程において強い介入を行っていることが外国資本の流入にマイナスとなったのである。

WTO 加盟は中国の比較優位をもつ園芸・畜産分野の生産と輸出拡大につながると予想される が，これらの分野における海外資本の導入は中国の比較優位を一層高めることになるものと思わ れる。表 3 は 1993 2001 年の中国農産物輸出・入の構造変化を示している。農産物全体としては 輸出額が輸入額を超えているが，「土地集約型作物とその加工品」（穀物・綿花・大豆を含む食物

表 3 農産物貿易の構成

\begin{tabular}{|c|c|c|c|c|c|c|c|c|c|c|c|c|}
\hline & \multicolumn{6}{|c|}{ 輸 } & \multicolumn{6}{|c|}{ 輸 } \\
\hline & \multirow[b]{2}{*}{$\begin{array}{c}\text { 金額 } \\
\text { (億 } \mathrm{US} \$ \text { ) }\end{array}$} & \multicolumn{5}{|c|}{ 構成比（\%） } & \multirow[b]{2}{*}{$\begin{array}{c}\text { 金額 } \\
\text { (億 US\$) }\end{array}$} & \multicolumn{5}{|c|}{ 構成比（\%） } \\
\hline & & $\begin{array}{l}\text { 土地集約 } \\
\text { 作物とそ } \\
\text { の加工品 }\end{array}$ & 園芸品 & 水産品 & 畜産品 & $\begin{array}{l}\text { その他 } \\
\text { 加工品 }\end{array}$ & & $\begin{array}{l}\text { 土地集約 } \\
\text { 作物とそ } \\
\text { の加工品 }\end{array}$ & 園芸品 & 水産品 & 畜産品 & $\begin{array}{l}\text { その他 } \\
\text { 加工品 }\end{array}$ \\
\hline 1993 & 114.8 & 26.4 & 24.2 & 14.4 & 17.0 & 18.0 & 39.5 & 41.1 & 8.0 & 14.9 & 20.5 & 15.5 \\
\hline 1994 & 144.9 & 22.6 & 22.8 & 18.0 & 17.8 & 18.8 & 71.6 & 61.9 & 2.2 & 12.2 & 13.0 & 10.7 \\
\hline 1995 & 146.9 & 9.6 & 28.9 & 22.5 & 21.4 & 17.6 & 121.7 & 69.6 & 4.4 & 7.9 & 9.4 & 8.7 \\
\hline 1996 & 143.2 & 10.8 & 29.2 & 21.2 & 22.0 & 16.8 & 108.3 & 56.6 & 7.0 & 11.1 & 10.2 & 15.1 \\
\hline 1997 & 150.6 & 16.4 & 25.7 & 20.9 & 20.1 & 16.8 & 99.7 & 50.0 & 5.8 & 12.2 & 10.4 & 21.5 \\
\hline 1998 & 139.4 & 17.4 & 26.5 & 20.4 & 19.3 & 16.3 & 83.4 & 45.9 & 5.3 & 12.3 & 12.0 & 24.6 \\
\hline 1999 & 136.0 & 15.8 & 25.7 & 23.1 & 18.5 & 16.9 & 82.4 & 41.4 & 5.9 & 15.8 & 18.4 & 18.6 \\
\hline 2000 & 157.0 & 47.4 & 23.4 & 24.4 & 18.6 & 16.2 & 112.5 & 39.9 & 6.7 & 16.4 & 18.7 & 18.2 \\
\hline 2001 & 126.3 & 11.9 & 25.8 & 25.8 & 188.8 & 17.7 & 97.1 & 42.1 & 6.9 & 14.9 & 16.5 & 19.6 \\
\hline
\end{tabular}

資料：中国税関総局資料による。 
油原料・食物油・製糖原料及び糖）の輸入額に占める割合は一貫して輸出額に占める割合よりも 大きいことがわかる。

\section{2 食品産業への影響}

中国の食品産業 (Food Industry) は，「食品加工業」(Food Processing)，「食品製造業」(Food Manufacturing)，「飲料製造業」，「煙草製造業」の4つの大分類業種に区分されている。「食品加 工業」と「食品製造業」の相違については曖昧な点があるが，加工度の高い製品を生産する産業 が「食品製造業」に分類されているようである。2000 年の中国食品産業の生産額は 6,910 億元 (833 億ドル)に達しており, 工業生産額の $1 / 12$ を占めている。中国の食品に占める加工食品の割合が $1 / 4$ に過ぎないとは言え, 国民一人当たりの平均所得水準を考えれば, 近年の中国食品産業は目覚 ましい成長を遂げつつあると評価できる（表 4 を参照）。

2000 年末時点で, 村営以上の「食品加工」企業数は 10,676 であり，「食品製造」企業数は 4,691 で，「飲料製造」企業数 は 3,409 となっている。前年度に比べて総生産額が増えた が，企業数が減少しているが，これは大企業による吸収合 併の結果であると思われる。

中国政府は, 食品産業を WTO 加盟後最も競争力が発揮 できる産業の一つとして期待しているが，アメリカ農務省 (USDA) は中国の食品産業における強み, 弱み, 機会, 脅

表 4 食品製造業の年平均成長率

\begin{tabular}{|c|c|}
\hline & 成長率 \\
\hline $1952-57$ & 17.10 \\
$1658-65$ & 3.36 \\
$1966-78$ & 8.17 \\
$1981-83$ & 9.11 \\
$1984-88$ & 10.71 \\
$1989-91$ & 4.96 \\
$1992-97$ & 23.15 \\
\hline
\end{tabular}

資料：「中国統計年鑑」各年版による。

表 5 中国の食品製造業の SWOT 分析

\begin{tabular}{|c|c|c|c|}
\hline 強 & 弱 & 機 & 威 \\
\hline $\begin{array}{l}\text { 世界最大の食品市場食品 } \\
\text { 部門は } 2 \text { 桁の成長率 }\end{array}$ & $\begin{array}{l}\text { 細かく分断された市場人 } \\
\text { 口の } 65 〜 70 \% \text { が地方に } \\
\text { 分散している。 }\end{array}$ & $\begin{array}{l}\text { 中国は食品加工に関して } \\
\text { 未知であり, 海外の加工 } \\
\text { 技術に開かれている。 }\end{array}$ & $\begin{array}{l}\text { 知的財産権問題: 成功商 } \\
\text { 品は直ちに偽造され, 革 } \\
\text { 新的技術が盗まれる可能 } \\
\text { 性がある。 }\end{array}$ \\
\hline $\begin{array}{l}\text { 中国経済は生き残るのに } \\
\text { 十分な規模がある。 }\end{array}$ & $\begin{array}{l}\text { 貧弱な輸送とインフラが } \\
\text { 生産者, 加工業者, 流通 } \\
\text { 業者の妨げとなってい } \\
\text { る。 }\end{array}$ & $\begin{array}{l}\text { WTO 加盟が, 関税, 輸入 } \\
\text { 障壁の引たげ, 市場, 法 } \\
\text { 律の改革, 流通への参入 } \\
\text { につながる。 }\end{array}$ & $\begin{array}{l}\text { 非関税障壁や地域保護主 } \\
\text { 義は,WＷＯ加盟によっ } \\
\text { てもすぐには消滅しな } \\
\text { い。 }\end{array}$ \\
\hline $\begin{array}{l}\text { 生活水準の向上ととも } \\
\text { に, 健康教育によって消 } \\
\text { 費者はより高品質で多様 } \\
\text { な食事を求める。 }\end{array}$ & $\begin{array}{l}\text { 関税が価格競争を困難に } \\
\text { している。輸入手続きは, } \\
\text { コストが高く，面倒であ } \\
\text { る。 }\end{array}$ & $\begin{array}{l}\text { 外資企業がリーディング } \\
\text { エッジとり，輸入原材 } \\
\text { 料の利用も進む。 }\end{array}$ & $\begin{array}{l}\text { 地方の生産者はすぐに追 } \\
\text { いつき, 新製品の製品寿 } \\
\text { 命は短い。 }\end{array}$ \\
\hline $\begin{array}{l}\text { 都市の生活スタイルの変 } \\
\text { 化によって, より多くの } \\
\text { 加工食品を消費する。 }\end{array}$ & $\begin{array}{l}\text { 農業生産が商業的食品加 } \\
\text { 工業と十分に統合されて } \\
\text { いない。 }\end{array}$ & $\begin{array}{l}\text { 農業の未発達は, 加工業 } \\
\text { 者が基本的原材料さえも } \\
\text { 輸入する必要があること } \\
\text { を意味する。 }\end{array}$ & $\begin{array}{l}\text { 中国国内における外国企 } \\
\text { 業の競争は熾烈である。 }\end{array}$ \\
\hline $\begin{array}{l}\text { 低賃金の構造が，高付加 } \\
\text { 価値生産の基礎を作る。 }\end{array}$ & & $\begin{array}{l}\text { 中国企業は, 投資, マー } \\
\text { ケティイグ, パッケージ } \\
\text { ング, 経営管理の支援を } \\
\text { 求めている。 }\end{array}$ & \\
\hline
\end{tabular}

資料：USDA [14]による。 
威の 4 つの側面から分析を行っている(表 5 を参照)。中国の食品産業に対する評価は, 成長の要 因がある一方で，農業との連携や流通過程に対する問題などから，必ずしも楽観的なものばかり ではない。

現在，外国の食品産業は中国の食品産業と競争する場合，二つの挑戦を受けることになる。一 つは国内食品産業の低価格商品であり，もう一つは先進的な技術を導入する外資企業の高品質商 品である。また，流通業者の間では，技術的により洗練された商品ほど低コストの中国製造品と の競争を免れやすいという認識が一般的である。なぜならば，ある新技術・新製品が導入されて からより安い中国製類似品が出るまでの寿命はおよそ5〜6 年なのである。

\section{3 食品流通業への影響}

中国の流通業はいまだに発展の低い段階にあり，商品コストのうち流通関係に要する費用が 30\% を占めているが，アメリカの場合は流通コストが 10\%程度である(USDA [14])。流通業の 発展が遅れている原因はハード面（輸送手段・道路整備など）とソフト面（各種の規制）の両方 にあると考えられる。1999 年における中国流通業の国内総生産 (GDP) に占める割合は 8.4\%で あったが, 先進国の日本(12.5\%), アメリカ $(15.7 \%)$ には及゙ないものの,ドイツ $(7.8 \%)$, スウェー デン $(8.3 \%)$ よりは大きく，国民経済の一大産業になりつつある(OECD [9], p. 305)。また，1996 年に打ける食品卸売業の販売額は $8,346.2$ 億元 (卸売業全体の $24.9 \%$ を占める) であり，小売業の 販売額は $2,413.5$ 億元 (小売業全体の $26.7 \%$ を占める) である (『中国統計年鑑 1997 年』中国統計 出版社 p. 567)。

しかし, 中国流通業の対外開放の開始は 1992 年からであり, 国営企業の独占状態が続いている ため，外資の参入には多くの障壁が立ちはだかっている。表 6 は中国の卸売業および小売業の状 況を描いている。その特徴は企業数・店舗数・従業員数において国内企業のシェアが圧倒的であ るうえ，なかでも特に国営企業・公営企業の割合が大きいことである。しかしながら，圧倒的な 資源を持つ国内の国営・公営企業はマーケット・シェアが小さく, 経営効率の悪さが際立ってい

表 6 流通業における企業形態別シェア（1995 年）

\begin{tabular}{|l|c|c|c|c|c|c|}
\hline & \multicolumn{3}{|c|}{ 卸売業 } & \multicolumn{3}{c|}{ 小売業 } \\
\hline & 企業数 & 店舗数 & 従業員数 & 企業数 & 店舗数 & 従業員数 \\
\hline 国有企業 & 63.3 & 65.9 & 66.8 & 48.4 & 44.6 & 45.1 \\
集体企業 & 17.9 & 16.7 & 17.7 & 26.7 & 22.9 & 16.6 \\
有限・株式会社 & 12.0 & 12.0 & 12.6 & 13.8 & 21.2 & 27.9 \\
私有企業 & 2.4 & 1.6 & 0.6 & 3.7 & 2.4 & 2.2 \\
華僑資本企業 & 0.3 & 0.3 & 0.1 & 1.0 & 1.0 & 1.7 \\
外資企業 & 0.3 & 0.5 & 0.3 & 0.8 & 3.2 & 2.2 \\
その他 & 3.7 & 3.0 & 1.9 & 5.4 & 4.6 & 4.3 \\
\hline
\end{tabular}

資料: OECD [9] p. 304 より作成。

注） 卸売業は年間販売額 2 千万元以上, 従業員数 20 人以上, 小売業は年間販売額 500 万元以上, 従業員数 60 人以上。 
表 7 食品流通業の概況（1996 年）

\begin{tabular}{|l|r|r|}
\hline & \multicolumn{1}{|c|}{ 卸売 } & \multicolumn{1}{c|}{ 小売 } \\
\hline 企業数 & 656,791 & $5,177,416$ \\
従業員数 (人) & $3,757,963$ & $10,738,924$ \\
販売額 (億元) & 8,346 & 2,414 \\
\hline
\end{tabular}

資料：『中国統計年鑑』による。

る。実際，1999 年における国内の国営・公営企業のマーケット・シェアはそれぞれ $18.2 \%, 15.6 \%$ に過ぎず，合弁企業・外資企業を含む「その他」企業のマーケット・シェアが $23 \%$ にも達してい る。一方, 食品流通業については必ずしも十分なデータが得られていないため, 概況のみ表 7 に まとめた。

通常, 中国では食品流通の目的に沿って, 国土を三つの地域, すなわち, 東北地域(北京市, 天 津市，旧満州を含む），華東地域（山東省から福建省までの沿海地域であり，上海市・江蘇省・浙 江省・安徽省・広東省を含む)，西部地域（それ以外）に分類している。しかし，このうち西部地 域においては，食品の卸売・小売業および食品市場のいずれも発展が遅れている。

$\mathrm{WT} \mathrm{O}$ 加盟後の $3 \sim 5$ 年の間に中国の流通業は完全に海外へ開放することになる。このことは短 期的には中国の食品流通業に打撃を与えることになろう。とくに，食品卸売業にとっては海外直 接投資の増加に伴って，国内のマーケット・シェアが合弁・外資系の流通業者に奪われることに なるであろう。しかし，中・長期的な視点に立てば，国営企業の改革に一層の拍車をかけること になり, 非効率的な経営体質が改善されることによって食品流通業界にプラスの影響を与えるこ とは間違いないであろう。

\section{4. 中国のフードシステムと産業間・国際相互依存関係}

表 8 は, 1985 年および 1995 年時点における中国のフードシステムを国際産業連関表（27 部門 表)からまとめたものである。ここでは, 国内のフードシステムが農業, 食品工業, その他産業, 最終需要という 4 つの部門から構成され, さらに国外との関係として農業および食品工業におけ る輸入・輸出を考えている。食品流通業および外食産業については，特定の部門として把握でき ないため，それらは「その他産業」として一括して取り扱っている。

表 9 は, 国内の各部門が原材料をどの部門から調達しているのか, その構成を見たものである。 食品工業は, 国内農業部門からの調達割合が減り, 輸出や最終需要においても, 農業から食品工 業へのシフトが進んでいるが，とくに輸出においてその傾向が強いことがわかる。

次に各部門が，農業部門および食品工業部門からの供給に関してどの程度国外に依存している かについて分析する。 $k$ 部門への $l$ 部門からの中間投入 (もしくは最終需要) について，国外の $l$ 部門に依存する割合を国外依存指数 $(I F D)$ とし, 次式によって定義する。ただし, $X F$ は輸入額, $X D$ は国内供給額とし, 添え字は順に供給側部門, 需要側部門を意味している。したがって, 需 要サイドからみた国外依存度を考えていることになる。 
表 8 フードシステムにおける農業・食品工業の投入産出関係（1985 年・1995 年）

単位: $1,000 \mathrm{US} \$$

\begin{tabular}{|c|c|c|c|c|c|c|}
\hline 1985 & 農業 & 食品工業 & その他産業 & 輸出 & 最終需要 & 全体 \\
\hline 国内農業 & $14,921,246$ & $19,549,744$ & $12,547,833$ & $3,375,281$ & $54,374,515$ & $104,768,619$ \\
\hline 国外農業 & 17,455 & 827,200 & 332,320 & - & 68,159 & $1,245,134$ \\
\hline 国内食品工業 & $3,445,216$ & $4,832,555$ & $6,728,559$ & $2,628,382$ & $27,928,712$ & $45,563,424$ \\
\hline 国外食品工業 & 90,121 & 368,962 & 180,649 & - & 473,685 & $1,113,417$ \\
\hline 計 & $18,474,038$ & $25,578,461$ & $19,789,361$ & $6,003,663$ & $82,845,071$ & $152,690,594$ \\
\hline \multicolumn{7}{|l|}{1995} \\
\hline 国内農業 & $34,665,826$ & $44,780,137$ & $36,781,168$ & $2,893,968$ & $92,755,016$ & $211,876,115$ \\
\hline 国外農業 & 70,021 & $3,036,821$ & $2,065,131$ & - & 61,682 & $5,423,348$ \\
\hline 国内食品工業 & $14,472,874$ & $11,656,648$ & $16,315,799$ & $9,315,999$ & $76,563,170$ & $128,324,490$ \\
\hline 国外食品工業 & 6,265 & $2,996,156$ & $1,318,103$ & - & $2,276,196$ & $6,596,720$ \\
\hline 計 & $49,214,986$ & $62,469,762$ & $71,075,356$ & $12,209,967$ & $171,656,064$ & $352,220,673$ \\
\hline
\end{tabular}

資料：Asian International Input-Outoput Table 1985, Institute of Developing Economies, 1992 お よ び, Asian International Input-Outoput Table 1995, Institute of Developing Economies, 2001 より作成。

注）農業は, Paddy, Other Agricultural Products, Livestockの 3 部門から構成される。

表 9 国内外の農業・食品工業からの部門別投入金額割合（1985 年・1995 年）

\begin{tabular}{|l|c|c|c|c|c|c|}
\hline & 農業 & 食品工立 $: \%$ & その他産業 & 輸出 & 最終需要 & 全体 \\
\hline 国内農業 & $70.4 \rightarrow 80.8$ & $76.4 \rightarrow 71.7$ & $63.4 \rightarrow 51.7$ & $56.2 \rightarrow 23.7$ & $65.6 \rightarrow 54.0$ & $68.6 \rightarrow 60.2$ \\
国外農業 & $0.1 \rightarrow 0.1$ & $3.2 \rightarrow 4.9$ & $1.7 \rightarrow 23.4$ & $-\rightarrow-$ & $0.1 \rightarrow 0.0$ & $0.8 \rightarrow 1.5$ \\
国内食品工業 & $29.4 \rightarrow 18.6$ & $18.9 \rightarrow 18.7$ & $34.0 \rightarrow 23.0$ & $43.8 \rightarrow 76.3$ & $33.7 \rightarrow 44.6$ & $29.8 \rightarrow 36.4$ \\
国外食品工業 & $0.0 \rightarrow 0.5$ & $1.4 \rightarrow 4.8$ & $0.9 \rightarrow 1.9$ & $-\rightarrow-$ & $0.6 \rightarrow 1.3$ & $0.7 \rightarrow 1.9$ \\
\hline \multicolumn{1}{|c|}{ 合計 } & 100.0 & 100.0 & 100.0 & 100.0 & 100.0 & 100.0 \\
\hline
\end{tabular}

資料: 表 8 より作成。

注） 各欄の左側が 1985 年，右側が 1995 年の数値である。

$$
I F D_{l k}=X F_{l k} / X D_{l k} \times 100
$$

表 10 は，国外の農業・食品工業への依存度を計算したものである。それによれば，1985 年から 1995 年にかけて, 全体的に国外依存度は上昇傾向にあるが, 食品工業の国外依存度の上昇が大き いことがわかる。とくに国外食品工業とのリンケージが強まっているのである。

そして表 11 は, 国内外の農業および食品工業部門の供給について，それぞれの供給先部門別の シェアをまとめたものである。国外製品は国内製品と比較して, 最終需要向けの供給割合が低く, 加工用・業務用など産業向け供給割合が高いことが特徵である。とくに国外の農産物はその傾向 が強い。国内農業は，その供給先を最終需要から食品工業・その他産業への重点を移しつつある。 しかしながら，それ以上に国外の農業や食品工業からの供給が増加しているため，結果としてそ 
表 10 国外の農業・食品工業への依存度（1985 年・1995 年）

\begin{tabular}{|l|c|c|c|c|c|}
\hline \multicolumn{1}{|c|}{} & 農業 & 食品工業 & その他産業 & 最終需要 & 全体 \\
\hline $\begin{array}{c}\text { 国外農業への } \\
\text { 依存度 }\end{array}$ & $0.1 \rightarrow 0.2$ & $4.1 \rightarrow 6.4$ & $2.6 \rightarrow 5.3$ & $0.1 \rightarrow 0.1$ & $1.2 \rightarrow 2.5$ \\
\hline $\begin{array}{c}\text { 国外食品工業 } \\
\text { 依存度 }\end{array}$ & $2.5 \rightarrow 0.0$ & $7.1 \rightarrow 20.4$ & $2.6 \rightarrow 7.5$ & $1.7 \rightarrow 2.9$ & $2.4 \rightarrow 4.9$ \\
\hline
\end{tabular}

資料：表 8 より作成。

注） 各欄の左側が 1985 年, 右側が 1995 年の数值である。

表 11 国内外の農業・食品工業部門における製品供給先割合（1985 年・1995 年）

\begin{tabular}{|l|c|c|c|c|c|c|}
\multicolumn{1}{|c|}{ 単位: \% } \\
\hline & 農業 & 食品工業 & その他産業 & 輸出 & 最終需要 & 全体 \\
\hline 国内農業 & $14.2 \rightarrow 16.4$ & $18.7 \rightarrow 21.1$ & $12.0 \rightarrow 17.4$ & $3.2 \rightarrow 1.4$ & $51.9 \rightarrow 43.8$ & 100.0 \\
国外農業 & $1.4 \rightarrow 1.3$ & $66.4 \rightarrow 56.0$ & $26.7 \rightarrow 38.1$ & $-\rightarrow-$ & $5.5 \rightarrow 1.1$ & 100.0 \\
国内食品工業 & $7.6 \rightarrow 11.3$ & $10.6 \rightarrow 9.1$ & $14.8 \rightarrow 12.7$ & $5.8 \rightarrow 7.3$ & $61.3 \rightarrow 59.7$ & 100.0 \\
国外食品工業 & $8.1 \rightarrow 0.1$ & $33.1 \rightarrow 45.4$ & $16.2 \rightarrow 20.0$ & $-\rightarrow-$ & $42.5 \rightarrow 34.5$ & 100.0 \\
\hline
\end{tabular}

資料：表 8 より作成。

注） 各欄の左側が 1985 年, 右側が 1995 年の数値である。

のシェアは縮小している。

このように, WTO 加盟以前から進行している中国のフードシステムの構造変化には, 国外の食 品工業と国内の食品工業および関連産業のリンケージの強化が，その中心にあることが明らかと なった。

\section{5. 結 語}

中国経済は 1990 年代後半に高度成長期から構造調整期へと移行してきている。しかしながら, これまで様々な政策を打ち出してきたが，期待していたほどの効果が上げられなかった。その原 因には，ポリシー・デザインの問題，政策実施の問題，利権争いの問題の三つがあると考えられ る。まず，ポリシー・デザインの問題に関して言えば，長期的なビジョンを持ち，かつダイナミッ クな政策設計例が少なく，部分的・局地的かつ断片的な政策が多く，しかも即効性を求めるもの が多かった。例えば，格差是正のために「八七扶貧攻堅計画」が打ち出された。「八七扶貧攻堅計 画」とは 1994 年に打ち出された貧困撲滅政策である。当時中国農村に推計約 8 千万人の絶対的貧 困者が存在しており,これらの人々を 2000 年までに貧困状態から脱出させるのがこの政策の目的 である (Kiminami [5])。しかし，2000 年までの期限付き政策であったため，負困問題の抜本的 な解決にどれだけの効果があったのかについては疑問が残るものであった。また，仮に良くデザ インされた政策であっても，実施においては部門間・地域間の連携がその前提となる。とくに，環 境問題および産業構造調整問題をめぐっては, 部門間・地域間の縄張り意識が未だに強い中国で 
は，利権の争いが政策の実施コストを高め，目標達成を妨げる要因となることがしばしばである。

WTO 加盟は, 中国のポリシー・メーカーにとって国内改革を一層進めるためのある種の外圧と なる。フードシステム全体を見ると,WTO 加盟後の一定期間内では部分的にマイナスの影響を受 けることが避けられない。とくに農業，なかでも穀物生産農家はかなりの打撃を受けることが予 想される。しかし，それに対応する新たな戦略が動き出していることも見逃してはならない。例 えば近年における「緑色食品」の急速な成長の裏には，今までとはかなり異なる発想の戦略を読 みとることができる。

「緑色食品」(Green Food) とは，「中国緑色食品発展センター」(CGFDC, 1990 年北京市に設 立）の定義によれば, 「安全, 優良な品質, 健康に良い食品（原料および加工品を含む）」の総称 である。中国の緑色食品は，その生産，環境，流通条件などに対する要求の違いによって大きく A A 級と A 級という二つの等級に分けられる (http://www.greenfood.org.cn/を参照)。現時点に おいて農産物の総生産量に占める「緑色食品」の割合は $1 \%$ に過ぎないが, 2002 年 6 月末までに 認証された商品は 2,791 個であり, 1,402 社の企業が「緑色食品」の生産に携わっている。また,「緑 色食品」の輸出額は 42 億ドルに達しており, 1997 年の 5 倍になっている。一部の農産物・食品に ついては,「緑色食品」が全体に占める割合は高く, 粉ミルクの場合は $40 \%$, 飲料の場合は $5 \%$ に 達している。また，糖料作物の作付面積の $10 \%$, 茶畑の $10 \%$ が「緑色食品」の基準を満たしてい る。「緑色食品」が中国の食品全体に占める割合は必ずしも高い訳ではないが，「緑色食品」の発 展は, 低コスト・高品質・安全性の高い農産物の生産, 加工, 流通を伴うという点で重要な意味 を持っている。この動きは, フードシステムにおける部門間のリンケージの量的な変化だけでは なく，農産物の高級化や差別化といった質的な変化を伴ったフードシステムの構造変化の動きと も関係している。

ただし, 中国の WTO 加盟による影響には様々な要因が関係している。例えば, WTO 加盟後の データの検証はまだ充分には行われていないが, 少なくとも 2002 年の農業の動向については予想 とは異なる結果が指摘されている（阮 [7] を参照)。すなわち, 土地集約型農産物の輸入が減少 した一方で輸出が増加し, 労働集約型農産物の輸出が予測されたほどの急速な伸びがなかうたの である。その要因として, 異常気象による海外農産物価格の高騰や先進諸国の食品検疫体制の強 化などが考えられるが，農村の貧困問題や地域間格差問題にも，同様の要因が影響することにな ろう。さらには，現在進められている農業の構造調整の進捗状況が大きく影響するものと考えら れる。それらの影響に関する検証については今後の研究課題としたい。

\section{参考文献}

[1] Anderson Kym, Huang Jikun and Ianchovichina Elena, "Impact of China's WTO Accession on Rural-Urban Income Inequality", CCAP Working Paper, 02-E2, 2002.

[2] Colby Hunter, Diao Xinshen and Tuan Francis, China's WTO Accession: Conflicts with Domestic Agricultural Policies and Institutions, IFPRI, 2001.

[3] 国務院発展研究中心『加入 WTO 後的中国: 戦略与改革」, 2002. 
[ 4 ] Huang Jikun and Scott Rozelle, "China's Accession to WTO and Shifts in the Agriculture Policy", CCAP Working Paper, 02-E4, 2002.

[5] 木南章・木南莉莉, 「食品産業の国際分業とフードシステム」, 高橋正郎・斎藤修編『フードシステム学 の理論と体系』, 農林統計協会, pp. 102-115, 2002.

[6 ] Kiminami, Lily Y., "A Basic Analysis of the Poverty Problem in China," FASID-IDRI Occasional Paper, No. 13, pp. 1-35, 1999.

［7］阮蔚「WTO 加盟 1 年目の中国農業の動き」『農林金融』2003.3, pp. 24-42, 2003.

［8］盧鋒「中国 WTO 加盟の国内農業部門に及ぼす影響一地域的パターン」山澤逸平・今井健一編『中国の WTO 加盟ーグローバル・エコノミーとの共生を目指して』アジア経済研究所, 2001.

[9] OECD, China in the World Economy: The Domestic Policy Challenges, 2002.

[10］斎藤修『フードシステムの革新と企業行動』, 農林統計協会, 1999.

[11］高橋正郎『フードシステム学の世界一食と食料供給のパラダイム』, 農林統計協会; 1997.

[12] 高橋正郎, 「フードシステム学とその課題」, 高橋正郎・斎藤修編『フードシステム学の理論と体系」, 農 林統計協会, 2002 .

[13］時子山ひろみ，『フードシステムの経済分析』，日本評論社，1999.

[14] USDA, “China, Peoples Republic of Market Development Reports, The Ripening of China's Food Processing Sector 2002," GAIN Report \# CH2809, 2002. 


\title{
China's Food System after its Accession to WTO
}

\author{
Lily Y. Kiminami*, Akira Kiminami**
}

The economic growth of China in recent years brings a big change to its supply and demand structure of the food. China is remarkable as the source of supply of the food to the foreign countries in addition to the huge food consumer market, too.

It is expected that China's accession to the WTO has a big influence on the Chinese agriculture about which the international competitiveness is weak. But it is also expected that it brings a big change to the whole food system.

Moreover, it will have a big influence on the agriculture and the food industry in the Asian countries which are deepening a mutual-dependence relation, too.

Therefore, in this study, first, we will make the influence clear which China's accession to the WTO gives the food system in China after analyzing the present situation of the food system in China.

Next, we will analyze the mutual-dependence relation of the food industry and the Asian countries in China using the international input-output table.

Then, we will analyze about the influence which China's accession to the WTO gives the food system in the Asian area and propose a policy to build cooperative relation in the Asian area.

*Niigata University

** University of Tokyo 